\title{
Hiehonkasvatuksen ulkoistamisen liiketaloudelliset hyödyt ja haasteet
}

Kati Partanen ${ }^{(1}$, Hannu Viitala ${ }^{(1}$, Seppo Mönkkönen ${ }^{(1}$, Risto Kauppinen ${ }^{(1}$, Veli-Matti Tuure ${ }^{(2}$, Tapani Kivinen $^{(3}$ ja Olli Ruoho ${ }^{(4}$

${ }^{1)}$ Savonia-ammattikorkeakoulu, PL 72, 74101 Iisalmi, etunimi.sukunimi@savonia.fi

${ }^{2)}$ TTS Työtehoseura, PL 5, 05201 Rajamäki, etunimi.sukunimi@ @ts.fi

${ }^{3)}$ Maa- ja elintarviketalouden tutkimuskeskus, Vakolantie 55,03400Vihti, etunimi.sukunimi@mtt.fi

${ }^{4)}$ Eläintautien torjuntayhdistys ETT ry, PL 221,60101 Seinäjoki, etunimi.sukunimi@ett.fi

\section{Tiivistelmä}

Hiehonkasvatuksen ulkoistamisella tavoitellaan taloudellista hyötyä lypsykarjatilalle. Samalla on mahdollista luoda uusia yritysmahdollisuuksia, erikoistuneita hiehokasvattamoita, maaseudulle. Hiehonkasvatuksen ulkoistamisen taloudellista kannattavuutta on tarkasteltava tilakohtaisesti, mutta yleisiä hyötyjä ja haasteita on kuitenkin löydettävissä. Hiehohotelli -hankkeessa on etsitty kriittisiä kohtia ulkoistamisen kannattavuudessa. Mitkä tekijät puoltavat hiehonkasvatuksen ulkoistamista ja mitkä voivat olla sen esteenä?

Hankkeessa tarkasteltiin tilamallien pohjalta hiehonkasvatuksen ulkoistamisen taloudellista mielekkyyttä sekä ulkoistamisen hyötyjä ja haasteita. Käytetyt tilamallit pohjautuvat todellisiin maatiloihin, joille on laskettu katetuottomenetelmän mukaista taloussuunnitelmaa hyväksi käyttäen kannattavuus nykyiselle tuotantotavalle sekä vaihtoehtoiselle tuotantotavalle, joka liittyy hiehonkasvatuksen ulkoistamiseen.

Hankkeessa tehtyjen laskelmien ja selvitysten perusteella voidaan todeta, että hiehonkasvatuksen ulkoistaminen on lypsykarjatilalle kannattavaa, mikäli sen avulla saadaan lisättyä tilalla tuotetun maidon määrää. Jos nuorkarjalta vapautuneille paikoille saadaan lypsylehmiä, saadaan tuotantorakennus tehokkaampaan käyttöön. Pelkkä säästö investointikustannuksissa tai työmäärässä ei välttämättä ole taloudellisesti riittävä kannuste hiehonkasvatuksen ulkoistamiseen. Kannattavuuden parantuminen riippuu kasvatuspäivän hinnasta, maidon hinnasta, työmenekin muutoksesta sekä mahdollisista investointikustannuksista, joita voi aiheutua tuotantorakennuksen remontoinnista.

Hiehokasvattamon kannattavuudessa kriittisiä tekijöitä ovat kasvatuspäivän hinta ja kasvattamon täyttöaste. Muita kannattavuuteen vaikuttavia tekijöitä ovat rehujen hinta, työmenekki ja investointikustannukset. Kasvattajalta vaaditaan rautaista ammattitaitoa. Erikoistuneen hiehonkasvatuksen etuina ovat kasvattamon ja sen kaikkien toimintojen suunnittelu nimenomaan hiehon tarpeita varten: rehuntuotanto, rakennus, työtavat jne. Lisäksi koko ketjuun heijastuvana etuna voidaan pitää sitä, että ulkoistamisessa hiehon kasvatuksen kustannukset tulevat näkyviksi, jolloin voidaan päästä eroon ns. hiehoautomaatista.

Haasteina on sopivan, sitoutuneen yhteistyökumppanin löytyminen sekä kasvatuspäivän hinnan määritteleminen molemmille osapuolille kannustavaksi. Yrityksen sijainti, rakennuskanta, työresurssit tai käytettävissä oleva peltoala voivat asettaa rajoituksia eläinmäärän muutoksille. On myös pidettävä mielessä, mikä on hiehonkasvatuksen tavoite: saada hyviä, ajallaan poikivia ensikoita lypsykarjatilan uudistukseen.

Hankkeen toteuttajina olivat Savonia-ammattikorkeakoulu, MTT, TTS Työtehoseura, ETT ja Evira. Rahoittajana oli Pohjois-Savon ELY-keskus.

Asiasanat: hiehot, kannattavuus, katetuotto, maidontuotanto, ulkoistaminen 


\section{Johdanto}

Maitotuotteiden kysynnän kehitys maailmanmarkkinoilla tuo suomalaiselle maidonjalostusteollisuudelle ja maidontuottajille mahdollisuuksia, mutta samalla myös vakavia haasteita. Vakaan tuottajahinnan markkinoilta on siirrytty tilanteeseen, jossa hinta vaihtelee. Myös maatalouspolitiikan muutokset tuovat paineita suomalaisen maidontuotannon kilpailukyvyn kehittämiseen.

Tuotannon laajentaminen on keino reagoida hintavaihteluihin, mutta se edellyttää maitotilalla usein suuria investointeja tuotantorakennukseen ja eläimiin. Tilan tuotannon siirtäminen huomattavasti suurempaan kokoluokkaan edellyttää aina myös hyvin suunniteltua työnkäytön järjestämistä ja hyvää logistiikan suunnittelua. Useimmiten lypsykarjatilalla kasvatetaan myös uudistukseen tuleva karja-aines. Hiehoilla on kuitenkin erilainen hoito, rehuvaatimus ja ruokinta kuin lehmillä.

Noin puolet hiehon tuotantokustannuksesta on muuttuvia kustannuksia (rehut, kuivikkeet, lääkintä jne.) ja kolmannes työkustannusta. Loppuosa kustannuksesta jakautuu rakennus- ja konekustannusten sekä yleiskustannusten kesken. (ProAgria 2009)

Hiehohotelli -hankkeen suunnitteluvaiheessa oletettiin, että hiehonkasvatuksen siirtäminen maitotilan ulkopuolelle vapauttaa tilaa ja työpanosta lypsylehmien lisäämiselle ja parantaa näin maidontuotannon kannattavuutta. Hankkeessa haluttiin myös selvittää, kannattaako hiehonkasvatuksen ulkoistaminen uuden tuotantorakennuksen yhteydessä. Hiehonkasvatuksen ulkoistaminen avaa uusia mahdollisuuksia kotieläintuotantoon hiehonkasvatusyrittäjyyden muodossa. Hankkeessa haluttiin selvittää, millä edellytyksillä erikoistunut hiehonkasvatusyrittäjyys on mahdollista ja mitkä ovat sen kriittiset kohdat.

Hankkeen toteuttajina olivat Savonia-ammattikorkeakoulu, MTT, TTS Työtehoseura, ETT ja Evira. Rahoittajana oli Pohjois-Savon ELY-keskus. Hanke toteutui vuosina 2009 - 2011.

\section{Aineisto ja menetelmät}

Toimintamallin taloudellista mielekkyyttä tarkasteltiin sekä hiehonkasvatuksen ulkoistajan (lypsykarjatila), että hiehonkasvattajan näkökulmista katetuottomenetelmän mukaista taloussuunnitelmaa käyttäen. Laskentaa varten valittiin case-tarkasteluun todellisia maatiloja, joille laskettiin kannattavuus nykyiselle tuotantotavalle sekä vaihtoehtoiselle tuotannolle, joka liittyy hiehonkasvatuksen ulkoistamiseen.

Selvitystä varten laadittiin viisi tilaesimerkkiä: 1) keskikokoinen lypsykarjatila, joka ulkoistaa hiehonkasvatuksen, 2) keskikokoinen lypsykarjatila, joka vaihtaa tuotantosuuntaa ja rakentaa uuden hiehokasvattamon, 3) yhden lypsyrobotin lypsykarjatila, joka lisää lehmämäärää ulkoistamalla hiehonkasvatuksen, 4) uuden ison lypsykarjanavetan rakentaminen nuorkarjapaikoilla ja ilman sekä 5) uusi hiehokasvattamo, jossa vaihtoehtona on sonnivasikoiden välikasvattamona toimiminen hiehokasvattamon lisäksi (ns."mixed model").

Katetuottomenetelmän mukainen taloussuunnitelma mahdollistaa vaihtoehtojen välisen vertailun. Menetelmässä voidaan vakioida tekijöitä, kuten tuotantopanosten hinta. Kun muutetaan vain niitä tekijöitä, jotka todellisuudessakin vaihtoehtojen välillä eroavat, saadaan esiin kannattavuuserot vaihtoehtojen välillä. Varioimalla eri tekijöitä, kuten maidon hintaa, hiehon kasvatuspäivän hintaa, investointikustannusta tai työmäärää pitäen samalla muut tekijät vakiona, löydetään tekijät, jotka vaikuttavat voimakkaimmin kannattavuuden muutoksiin.

Tilatasolla päätöksiä tehtäessä tilakohtaiset rajoitteet on otettava huomioon. Siksi hankkeessa käytettiin laskelmissa case-tiloja, joille laskettiin kannattavuus nykyiselle tuotannolle sekä vaihtoehdolle. Näin mallintamalla pyrittiin kuvaamaan mahdollisimman todenmukaista yrittäjän päätöksentekotilannetta.

Tuloksista tarkasteltiin erityisesti yrittäjätuloa ja kannattavuuskerrointa. Yrittäjätulo on yrittäjän omalle työlle ja pääomalle saatava korvaus. Kannattavuuskerroin saadaan, kun yrittäjäperheen palkkavaatimuksen ja oman pääoman korkovaatimuksen summa jaetaan yrittäjätulolla. Se siis osoittaa, kuinka hyvin tavoitteeseen päästään. Esimerkkitapauksissa yrittäjäperheen palkkavaatimuksena käytettiin $14 \mathrm{e} / \mathrm{h}$ ja oman pääoman korkovaatimuksena $5 \%$ :a.

Työmäärän arviointi on suunnitteluvaiheessa hankalaa. Siksi laskentaan sisällytettiin TTS Työtehoseuran laskelmat työnkäytöstä ja tarvittaessa laskelmassa huomioitiin ulkopuolisen työvoiman palkkaaminen. Laskelmaan tarvittavat ruokinta- ja rakennuskustannustiedot saatiin MTT:Itä. Lisäksi toimintamalleissa otettiin huomioon ETT:n ja EVIRA:n asiantuntijoiden suositukset eläinliikenteestä. 


\section{Tulokset ja tulosten tarkastelu Ulkoistamisstrategiat}

Tila voi ulkoistaa hiehonkasvatuksen usealla eri tavalla. Eri tapoja erottavana tekijänä on eläinten siirtojen ja kerrallaan siirrettävien eläinten lukumäärä vuodessa TTS Työtehoseuran tekemien selvitysten mukaan näitä molempia tapoja on tiloilla käytössä.

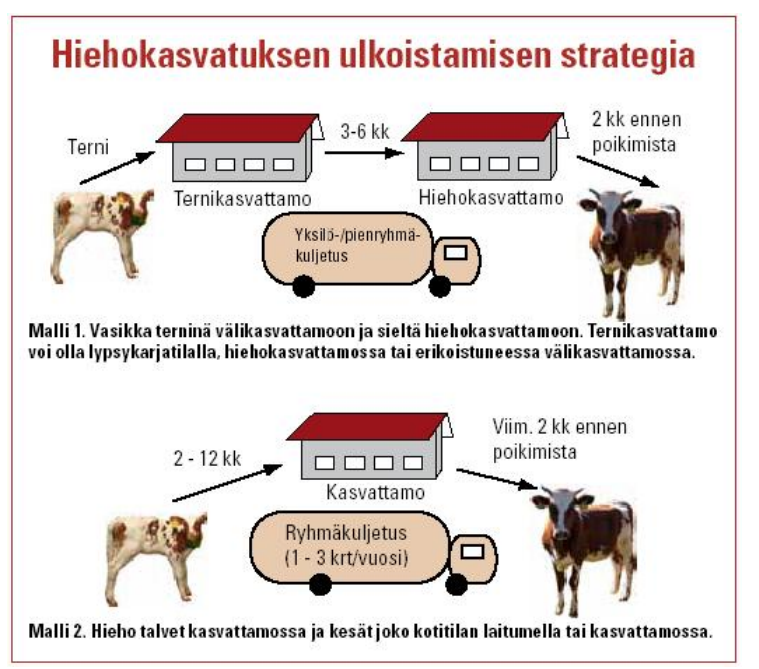

Kuva1. Hiehonkasvatuksen ulkoistamisen strategiat.

Osa tiloista siirtää aina tietyn ikäiset eläimet kasvattamoon, esimerkiksi ternivasikkana tai 4 kk ikäisenä vasikkana. Samoin siirto takaisin lypsykarjanavettaan tapahtuu aina samassa vaiheessa poikimiseen nähden, yleensä 2 kk ennen poikimista. Tilan koosta riippuen kerrallaan on siirrettävänä vain yksittäisiä eläimiä tai pieniä ryhmiä (Kuva 1, Malli 1).

Osa tiloista siirtää eläimet aina tiettyyn aikaan vuodesta, esimerkiksi laidunkauden päättyessä lypsykarjatilalta kasvattamoon ja takaisin taas laidunkauden alkaessa. Näin menetellään siinä tilanteessa, jos lypsykarjatila haluaa hyödyntää laitumet tehokkaasti ja tilalla on esim. perinnebiotooppeja, joita nuorkarja laiduntaa. Tässä tapauksessa siirrettävänä on kerrallaan isompi eläinryhmä (Kuva 1, Malli 2).

\section{Ulkoistamisen kannattavuus keskikokoisella lypsykarjatilalla}

Tarkasteltavana olleella keskikokoisella lypsykarjatilalla oli lähtötilanteessa 22 lypsylehmää. Navetassa oli kuitenkin lypsylehmien käyttöön otettavia parsipaikkoja, joten maidontuotantoa pystyttäisiin tehostamaan olemassa olevan rakennuksen sisällä. Tilalle laskettiin kaksi erilaista mallia ulkoistamisen: 1) nuorkarjan siirto lypsykarjatilan ja kasvattamon välillä kaksi kertaa vuodessa, eli isompina eläinryhminä (Kuva 1, Malli 2) ja 2) nuorkarjan siirto lähettäjän ja kasvattajan välillä yksilöinä tai pienryhminä niin, että vasikat siirretään kasvattamoon n. 4-5 kk iässä ja takaisin lypsykarjatilalle n. 2 kk ennen poikimista (Kuva 1, Malli 1). Navettaan hankittiin lisää lypsy-yksiköitä, jotta työmäärä ei kasvaisi kohtuuttomasti lehmämäärän lisääntyessä. Mallin 2 mukaan ulkoistettaessa nuorkarja lähtee kasvattamoon aina laidunkauden lopussa lokakuussa ja palaa takaisin lypsykarjatilalle toukokuussa laitumelle. Kasvattamossa eläimet siis ovat kerrallaan n. 7 kk ajan. Näin lehmämäärä saadaan nostettua 30:een. Koko navetan kapasiteettia ei saada hyödynnettyä, sillä tilaa tarvitaan sisäruokintakauden aikana poikiville hiehoille ja myös sisäruokintakauden aikaan syntyville vasikoille.

Kun tila ulkoistaa kasvatuksen mallin 1 mukaan, jolloin vasikat siirretään kasvattamoon n. kerran kuukaudessa ja tiineet hiehot palaavat takaisin noin kaksi kuukautta ennen poikimista, tila saa nostettua lehmämäärän 35:een. Tässä tapauksessa navetan maidontuotantokapasiteetti hyödynnetään hyvin tehokkaasti. Ongelmaksi saattaa kuitenkin muodostua työmäärä, jolloin erilaisia teknologiaratkaisuja kannattaa miettiä. 
Taulukko 1. Hiehonkasvatuksen ulkoistamisen taloudellisia vaikutuksia keskikokoiselle lypsykarjatilalle. Vertailua kahden eri ulkoistamisstrategian välillä.

\begin{tabular}{|c|c|c|c|c|c|}
\hline & $\begin{array}{l}\text { Ennen ulkois- } \\
\text { tamista }\end{array}$ & $\begin{array}{l}\text { Hiehonkasv. ul- } \\
\text { koistettu, siirto } \\
\text { kerran vuodessa } \\
\text { kasvattamoon } \\
\text { ryhmänä }\end{array}$ & $\begin{array}{l}\text { Erotus lähtö- } \\
\text { tilanteeseen }\end{array}$ & $\begin{array}{l}\text { Hiehonkasv. ulkois- } \\
\text { tettu, siirto kerran } \\
\text { kuukaudessa kasvat- } \\
\text { tamoon }\end{array}$ & $\begin{array}{l}\text { Erotus lähtö- } \\
\text { tilanteeseen }\end{array}$ \\
\hline Lypsylehmiä & 22 & 30 & +8 & 35 & +13 \\
\hline Tuotettu maitoa $(\mathrm{kg})$ & 200200 & 273000 & +72800 & 318500 & +118300 \\
\hline Poikivia hiehoja / vuosi & 9 & 12 & +3 & 14 & +5 \\
\hline $\begin{array}{l}\text { Kasvatuspäiviä yhteen- } \\
\text { sä, vrk (tilan ulkopuolel- } \\
\text { la) }\end{array}$ & & 2743 & & 5880 & \\
\hline $\begin{array}{l}\text { Ulkoistuskustannus } \\
\text { e/vuosi (*(alv 0\%) }\end{array}$ & & 7250 & & 16000 & \\
\hline Säilörehualan tarve, ha & 16 & 18 & +2 & 22 & +6 \\
\hline Laidunalan tarve, ha & 6,5 & 9 & $+2,5$ & 6,5 & 0 \\
\hline Lantamäärä, $\mathrm{m}^{3}$ & 660 & 750 & +90 & 900 & +240 \\
\hline Yrittäjätulo, $€$ & 27333 & 38142 & +10809 & 45159 & +17826 \\
\hline Kannattavuuskerroin & 0,33 & 0,45 & $+0,12$ & 0,50 & $+0,17$ \\
\hline Työtuntimäärä, h/vuosi & 3929 & 4072 & +143 & 4413 & +484 \\
\hline $\begin{array}{l}\text { Maidon hinta, } € / 1 \text { (ilman } \\
\text { tukialue } C 2: n \text { pohjoista } \\
\text { tukea) } \\
\text { (alv } 0 \% \text { ) }\end{array}$ & 0,3779 & 0,3779 & & 0,3779 & \\
\hline $\begin{array}{l}\text { Kasvatuspäivän hinta, } € \\
\text { (alv } 0 \% \text { ) }\end{array}$ & & 2,50 & & 2,50 & \\
\hline $\begin{array}{l}\text { Nettoinvestoinnit, } €(* * \\
(\operatorname{alv} 0 \%)\end{array}$ & & 6900 & & 15000 & \\
\hline
\end{tabular}

*) sisältää kasvatuskustannuksen, kuljetukset ja salmonellatestauksen

**) sisältää navetan muutoskustannuksen, lisälypsy-yksiköiden hankinnan ja lypsykoneen päivityksen.

Keskikokoiselle lypsykarjatilalle hiehonkasvatuksen ulkoistaminen on kannattavaa (taulukko 1.). Kun olemassa oleva tuotantorakennus saadaan mahdollisimman tehokkaasti maidontuotantokäyttöön, sekä yrittäjätulo että kannattavuuskerroin paranevat.

\section{Ulkoistamisen kannattavuus yhden robotin navetassa}

Toisena hiehonkasvatuksen ulkoistamisen tapauksena tarkasteltiin 70 lehmän pihattonavettaa, joka ulkoistaa hiehonkasvatuksen ja ottaa käyttöön toisen lypsyrobotin. Tilalla on 2000-luvun alussa rakennettu pihatto, joka on malliltaan keskikäytävänsä suhteen epäsymmetrinen. Vasikat lähtevät kasvattamoon $n$. kahden viikon iässä ja palaavat takaisin lypsykarjatilalle $2 \mathrm{kk}$ ennen poikimista. Lehmämäärä saadaan nostettua 125 :een, eli kahden robotin kapasiteettia ei täysin saada hyödynnettyä. Työmäärää kohtuullistaakseen tila päättää ulkoistaa pääosan peltotöistä.

Taulukko 2. Hiehonkasvatuksen ulkoistamisen taloudellisia vaikutuksia yhden robotin tilalla.

\begin{tabular}{|l|c|c|c|}
\hline & $\begin{array}{c}\text { Hiehonkasvatus lyp- } \\
\text { sykarjatilalla, yksi } \\
\text { lypsyrobotti }\end{array}$ & $\begin{array}{c}\text { Hiehonkasvatus ulkoistettu } \\
\text { ja kaksi lypsyrobottia }\end{array}$ & Erotus \\
\hline Lypsylehmiä & 70 & 125 & +55 \\
\hline Tuotettu maitoa (kg) & 623000 & 112500 & +489500 \\
\hline Poikivia hiehoja / vuosi & 28 & 30300 & +22 \\
\hline $\begin{array}{l}\text { Kasvatuspäiviä yhteensä } \\
\text { (tilan ulkopuolella), vrk }\end{array}$ & & 83000 & \\
\hline Ulkoistuskustannus e/vuosi & & 32300 \\
\hline
\end{tabular}




\begin{tabular}{|l|c|c|c|}
\hline$(*$ alv 0\%) & & & +37 \\
\hline Säilörehualan tarve, ha & 85 & 3300 & +600 \\
\hline Lantamäärä, $\mathrm{m}^{3}$ & 2700 & 137370 & +11985 \\
\hline Yrittäjätulo, € & 125385 & 1,38 & $+0,11$ \\
\hline Kannattavuuskerroin & 1,27 & 0,3779 & +610 \\
\hline Työtuntimäärä, h/vuosi & 4264 & 2,50 & \\
\hline $\begin{array}{l}\text { Maidon hinta (ilman tukialue } \\
\text { C2:n pohjoista tukea), } € / 1 \\
\text { (alv 0 \%) }\end{array}$ & 0,3779 & 19580 & \\
\hline $\begin{array}{l}\text { Kasvatuspäivän hinta, } €,(\text { alv } \\
0 \%)\end{array}$ & & 144840 & \\
\hline $\begin{array}{l}\text { Lisäkiintiön hankinta, 0,04 e } \\
\text { / litra (alv 0\%) }\end{array}$ & & & \\
\hline $\begin{array}{l}\text { Nettoinvestoinnit, } €(* * \\
\text { (alv 0\%) }\end{array}$ & & & \\
\hline
\end{tabular}

*) sis. kasvatuskustannuksen, kuljetukset ja salmonellatestauksen, **) sis. navetan muutoskustannuksen, lietelantalan, toisen lypsyrobotin hankinnan, maitokiintiön oston sekä tarpeettomaksi käyneiden peltotyökoneiden myynnin.

Tässä tapauksessa kannattavuuden paraneminen on varsin vähäistä ja sen voi katsoa jäävän normaalin vuotuisen vaihtelun sisään (taulukko 2). Erityisesti kannattavuuden paranemista heikentää lypsyrobottien kapasiteetin jääminen vajaaksi. Epäsymmetrisen pohjaratkaisun pihatoissa ei siis saada välttämättä navetan käyttöä tehostettua ilman merkittäviä investointeja.

\section{Ulkoistamisen kannattavuus uutta navettaa rakennettaessa}

Kolmas ulkoistajatapaus oli uuden pihattonavetan rakentaminen. Tässä tarkasteltiin sitä, kannattaako uuteen navettaan rakentaa tilat nuorkarjalle, vai ulkoistaa nuorkarjan kasvatus. Tilalla rakennetaan uusi, n. 160 lehmän pihattonavetta. Laskelmissa on huomioitu mahdollinen vajaatäyttö, joten eläinmääräksi on arvioitu keskimäärin 153 lehmää. Vaihtoehtoina on joko rakentaa navetan yhteyteen paikat nuorkarjalle, tai ulkoistaa hiehonkasvatus ja rakentaa navetta pelkästään lypsylehmille. Nurmialan tarve on ensimmäisessä vaihtoehdossa 24 hehtaaria suurempi, kuin ulkoistamisvaihtoehdossa.

Taulukko 3. Hiehonkasvatuksen ulkoistamisen taloudellisia vaikutuksia uuden lypsykarjapihaton rakentavalla tilalla.

\begin{tabular}{|c|c|c|c|}
\hline & $\begin{array}{l}\text { Hiehonkasvatus } \\
\text { lypsykarjatilalla }\end{array}$ & $\begin{array}{c}\text { Hiehonkasvatus } \\
\text { ulkoistettu }\end{array}$ & Erotus \\
\hline Lypsylehmiä & 153 & 153 & \\
\hline Tuotettu maitoa, $\mathrm{kg}$ & 1361700 & 1361700 & \\
\hline Poikivia hiehoja / vuosi & 61,2 & 61,2 & \\
\hline $\begin{array}{l}\text { Kasvatuspäiviä yhteensä, } \\
\text { vrk (tilan ulkopuolella) }\end{array}$ & & 39535 & \\
\hline $\begin{array}{l}\text { Ulkoistuskustannus } € / \text { vuosi } \\
(* \text { alv } 0 \%)\end{array}$ & & 101400 & \\
\hline Säilörehualan tarve, ha & 150 & 126 & -24 \\
\hline Lantamäärä, $\mathrm{m}^{3}$ & 4406 & 3680 & -600 \\
\hline Yrittäjätulo, € & 259538 & 247107 & -12431 \\
\hline Kannattavuuskerroin & 2,05 & 1,83 & $-0,22$ \\
\hline Työtuntimäärä, h/vuosi & 6187 & 5314 & -873 \\
\hline $\begin{array}{l}\text { Palkatun työvoiman tarve, } \\
\text { h/vuosi }\end{array}$ & 2000 & 1127 & -873 \\
\hline $\begin{array}{l}\text { Maidon hinta, } € / 1 \text { (ilman } \\
\text { tukialue } C 2: \text { pohjoista } \\
\text { tukea) (alv } 0 \% \text { ) }\end{array}$ & 0,3779 & 0,3779 & \\
\hline $\begin{array}{l}\text { Kasvatuspäivän hinta, } € \text { (alv } \\
0 \% \text { ) }\end{array}$ & & 2,50 & \\
\hline $\begin{array}{l}\text { Nettoinvestoinnit (** } \\
\text { (alv 0\%) }\end{array}$ & 1,734 M€ & 1,45 M€ & $-284000 €$ \\
\hline
\end{tabular}

*) sis. kuljetukset ja salmonellatestauksen **) erotus sis. nuorkarjan osaston navettaan ja lietelantalan laajennuksen 
Tässä tapauksessa hiehonkasvatus pystytään järjestämään tilalle rakennettavassa nuorkarjaosastossa niin tehokkaasti, ettei ulkoistaminen ole taloudellisesti kannattavaa, jos kasvatuspäivän hinta on 2,50 €/vrk (taulukko 3). Jos taas kas vatuspäivän hinta on $2 € /$ vrk, kannattavuusero vaihtoehtojen välillä on hyvin pieni, joten molemmat vaihtoehdot ovat varteenotettavia.

Laajentavalla tilalla on tekijöitä, jotka rajoittavat suunniteltua eläinmäärää. Esimerkiksi peltoalan saatavuus saattaa olla este eläinmäärän lisäämiselle ja tässä tapauksessa nuorkarjan kasvattamiselle omalla tilalla. Tällöin tilalla investoinnin yhteydessä punnitaankin sitä, rakennetaanko yhden robotin tila ja kasvatetaan nuorkarja itse vai kahden robotin tila ja ulkoistetaan nuorkarjan kasvatus.

\section{Erikoistuneen hiehokasvattamon kannattavuuden edellytykset}

Hiehokasvattamon kannattavuuden edellytysten tarkastelua varten tehtiin vertailulaskelmaa siitä, kannattaako keskikokoisen lypsykarjatilan luopua maidontuotannosta ja perustaa hiehokasvattamo. Toinen kasvattamotarkastelu tehtiin siitä, kannattaako ison, erikoistuneen kasvattamon kasvattaa vain hiehoja vai toimia myös ns. välikasvattamona sopimustilojen sonnivasikoille. Tavoitteena oli löytää erikoistuneen hiehonkasvatuksen kriittiset kohdat ja onnistumisen edellytykset.

Taulukko 4. Tuotantosuunnan vaihdoksen taloudellisia vaikutuksia, kun keskikokoinen lypsykarjatila luopuu maidontuotannosta ja perustaa hiehokasvattamon.

\begin{tabular}{|l|c|c|c|}
\hline & Lypsykarja & $\begin{array}{c}\text { Erikoistunut hiehon- } \\
\text { kasvatus }\end{array}$ & Erotus \\
\hline Lypsylehmiä & 22 & & \\
\hline Tuotettu maitoa (kg) & 200200 & & \\
\hline Hiehopaikkoja & 9 & 61560 & \\
\hline $\begin{array}{l}\text { Myytyjä kasvatuspäiviä } \\
\text { yhteensä, vrk/vuosi (täyttöas- } \\
\text { te 95\%) }\end{array}$ & 15 & 41 & +26 \\
\hline Säilörehualan tarve, ha & 663 & 2179 (liete) & +1516 (liete) \\
\hline $\begin{array}{l}\text { Lantamäärä, m } \\
\text { 3rittäjätulo, } €\end{array}$ & 28138 & 30746 & +100 (kuivikelanta) \\
\hline Kannattavuuskerroin & 0,34 & 0,57 & +2608 \\
\hline Työtuntimäärä, h/vuosi & 3929 & 2596 & +1333 \\
\hline $\begin{array}{l}\text { Kasvatuspäivän hinta, } € \\
\text { (alv 0\%) }\end{array}$ & & 2,50 & \\
\hline $\begin{array}{l}\text { Nettoinvestoinnit, } €(* \\
\text { (alv 0\%) }\end{array}$ & & 422000 & \\
\hline
\end{tabular}

*) sisältää rakennuksen ja koneet, investointiavustus otettu huomioon

Tässä esimerkissä tilan kannattavuus paranee, kun tila vaihtaa tuotantosuuntaa maidontuotannosta erikoistuneeseen hiehonkasvatukseen (taulukko 4). Yrittäjätulon kasvu jää vähäiseksi, mutta työmäärä pienenee. Hiehonkasvatuksessa on maidontuotantoon verrattuna erilaisia osaamisvaatimuksia, kuten palveluiden markkinointi ja yhteydenpito asiakkaisiin. Selvityksen mukaan erikoistuneen hiehokasvattamon kannattavuuteen vaikuttaa tuotantokustannusten lisäksi merkittävimmin kasvatuspäivän hinta ja täyttöasteen muutos.

"Mixed model" - versiossa ongelmaksi saattaa muodostua kasvattamon koko. Ainakin suurilla teurastamoilla vakiintunut välikasvatetun sonniryhmän koko on 30 eläintä, jotka ovat mahdollisimman saman ikäisiä. Tässä tapauksessa päästäisiin vain kolmasosaan siitä. On siis epävarmaa, löytyisikö yhteistyökumppania, joka ostaisi puolivuotiaat sonnit välikasvatettujen hinnalla. Siksi laskelma tehtiin myös vaihtoehdolle, jossa sonnit myydään normaaleina välitysvasikoina 4 kk iässä. 
Taulukko 5. Hiehokasvattamon ja "mixed model" -toimintamallin vertailua.

\begin{tabular}{|l|c|c|c|}
\hline & Hiehokasvattamo & $\begin{array}{c}\text { Mixed model } \\
\text { (4 kk ikään) }\end{array}$ & $\begin{array}{c}\text { Mixed model } \\
\text { (6 kk ikään) }\end{array}$ \\
\hline Myytyjä hiehoja /vuosi & 151 & 129 & 129 \\
\hline Myytyjä sonnivasikoita / vuosi & & 129 & 129 \\
\hline $\begin{array}{l}\text { "Myytyjä" kasvatuspäiviä } \\
\text { yhteensä }\end{array}$ & 97158 & 97158 & 57 \\
\hline Säilörehualan tarve, ha & 56 & 50 & 104560 \\
\hline Yrittäjätulo, $€$ & 106251 & 87889 & 1,09 \\
\hline Kannattavuuskerroin & 1,16 & 0,93 & 4023 \\
\hline Työtuntimäärä, h/vuosi & 3778 & 4023 & 54 \\
\hline
\end{tabular}

Esimerkkitapauksessa pelkkien hiehojen kasvattaminen olisi kannattavampaa, kuin malli, jossa toimitaan välikasvattamona sonnivasikoille (taulukko 5). Ero johtuu lähinnä siitä, että sonnivasikan markkinahinta on lehmävasikkaa korkeampi ja lisäksi sonnit ovat tilalla kaikkein kalleimman kasvatusajan, jolloin vasikka syö suhteessa enemmän kallista rehua (juottorehu, väkirehu). Jos tila löytää yhteistyökumppanin, joka on valmis ostamaan puolivuotiaat sonnit välikasvatetun naudan hinnalla, sekakasvattamovaihtoehto voi olla houkutteleva. Tällä toimintamallilla suurin etu olisi vajaatäytön riskin pienentäminen, kun kasvattamoon otettaisiin kaikki yhteistyötiloilla syntyvät vasikat.

\section{Johtopäätökset}

Hiehonkasvatuksen ulkoistamisella on hyvin järjestettynä mahdollisuus saavuttaa maidontuotannon tarvitsemaa erikoistumista ja lisätä kustannustehokuutta. Ulkoistaminen on case-esimerkkien perusteella kannattavaa, mikäli lypsykarjatila pystyy lisäämään tuotetun maidon määrää.

Mikäli maidon tuottajahinta laskee voimakkaasti, ulkoistamisen kannattavuus heikkenee. Myös kasvatuspäivän hinta vaikuttaa ulkoistamisen kannattavuuteen. Ulkoistaminen on sitä kannattavampaa, mitä suurempi keskituotos lypsykarjassa on.

Kasvatuspäivän hinnan määrittelyssä on otettava lähtökohdaksi hiehon tuotantokustannukset. Hinnan on oltava molempien osapuolten hyväksymä. Toisaalta hiehon kasvatuskustannukset tulevat tässä mallissa näkyväksi, jolloin uudistukseen kiinnitetään enemmän huomiota. Esimerkkilaskelmissa ei otettu huomioon sitä, että todennäköisesti lypsykarjatila harkitsee entistä tarkemmin uudistukseen tarvittavien eläinten määrää, kun niiden kasvatuksesta maksetaan ulkopuolisille. Näin saadaan hyvä kannuste esim. sukupuolilajitellun sperman käytölle, kun uudistusainesta halutaan vain parhaista lehmistä. Tämä taas saisi aikaan ns. hiehoautomaatin poistumisen. Monella tilalla joudutaan poistamaan hyvässä tuotosvaiheessa olevia lypsylehmiä,jotta uudistushiehoille saadaan riittävästi tilaa. Ennen pitkää tämä johtaisi karjan keskimääräisten poikimakertojen määrän kasvuun ja edelleen kannattavuuden paranemiseen, kun eläinpääomaa hyödynnetään entistä tehokkaammin. Toimintamallin päätavoite on saada entistä parempia ensikoita maitotilan tarpeisiin entistä tehokkaammalla resurssien käytöllä.

Laskelmat on tehty vakiintuneisiin tilanteisiin, eli tuotantosuunnan tai -määrän muutosvaiheen taloustarkastelua ei selvitykseen sisältynyt. Jatkossa olisikin syytä tarkastella, miten tilan maksuvalmiudelle tapahtuu, erityisesti siinä tilanteessa, kun tuotantosuunta vaihtuu maidontuotannosta hiehonkasvatukseen.

\section{Kirjallisuus}

Ehnroth, A., Österman, P. \& Hannele, T. (toim) 2003. Laajentavien tilojen haasteet. ProAgria Maaseutukeskusten Liiton julkaisuja 998. Tieto tuottamaan 104.

Karhula, T., Ylätalo, M., Ryhänen, M. \& Latukka, A. 2002. Maitotilojen taloudellinen tulos ja kannattavuus 2000 - 2010. Helsingin yliopisto. Taloustieteen laitos. Julkaisuja 37: 155-213.

MTT. 2011. Taloustohtori. Saatavilla: http://www.mtt.fi/taloustohtori

Pellinen, J., Ehnroth, A. \& Harmoinen, T.(toim) 2008. Kannattava maatilayritys. ProAgria Maaseutukeskusten Liiton julkaisuja 1060. Tieto tuottamaan 124.

ProAgria 2009. Mallilaskelmia maataloudesta 2009. 48 s.

Ryhänen, M. \& Sipiläinen, T. \& Latukka, A. 2002. Maatalousyrityksen tuotannon suunnittelu ja kehittäminen. Helsingin yliopisto. Taloustieteen laitos. Opetusmoniste. Luonnos 3/2003. 169 s.

Ylätalo, M. \& Mäkinen, H. 1997. Maatilatalouden investoinnit, rahoitus ja maksuvalmius. Helsingin yliopisto. Taloustieteen laitoksen monistesarja 12:1-121. 